\title{
The role of VATS in the diagnosis and treatment of diaphragmatic injuries after penetrating thoracic traumas
}

\author{
다 Fazlı Yanık, M.D., 다 Yekta Altemur Karamustafaoğlu, M.D., 다 Yener Yörük, M.D.
}

Department of Thoracic Surgery, Trakya University Faculty of Medicine, Edirne-Turkey

\begin{abstract}
BACKGROUND: Diaphragmatic injuries, which can be seen after penetrating thoracic traumas, have some difficulties in diagnosis. Undiagnosed small diaphragmatic lacerations may lead to serious health problems. This study aims to evaluate the role of VATS (Video Assisted Thoracoscopic Surgery) in the diagnosis and treatment of diaphragmatic injuries after penetrating thoracic traumas.

METHODS: Among 268 penetrating thoracic trauma patients, we retrospectively evaluated a total of 22 patients performed VATS due to suspected diaphragmatic injury in our department between June 2008 and June 2018.

RESULTS: Twenty (9I\%) patients were male, and two (9\%) patients were female with a mean age of $28.01 \pm 6.4$ (I8-42) years. In II $(50 \%)$ patients, VATS was performed on the right side and the others on the left side according to the penetrating area of trauma. In 10 (45\%) patients, diaphragmatic laceration was detected and was repaired. In six cases (27\%) in which diaphragmatic laceration detected with VATS, preoperative traumatic pathologies were detected radiologically. The missed injury rate was $18 \%$. VATS had a specificity, sensitivity, positive predictive value and negative predictive value of $75 \%, 71.5 \%, 60 \%$ and $83.3 \%$, respectively. There was no significant statistical difference between types of penetrating trauma, ages and gender of cases $(p>0.05)$. No complication was detected during the mean follow up period of 36.2 \pm 9.3 (range 9-62) months.
\end{abstract}

CONCLUSION: Our opinion is that VATS is important and feasible in hemodynamically stable patients with suspected isolated diaphragmatic laceration after penetrating thoracic trauma that cannot be determined by radiologically.

Keywords: Diaphragma; penetratin; thoracoscopy; trauma.

\section{INTRODUCTION}

The most common cause of death in the first four decades of life is trauma. Approximately $20-25 \%$ of these deaths are due to thoracic trauma. Thoracic injuries are responsible for mortality in $50 \%$ of trauma deaths. Many deaths occurring within minutes or a few hours of injury can be prevented with rapid diagnosis and appropriate treatment of trauma. ${ }^{[1,2]}$ We can basically divide the thoracic trauma as blunt, penetrating, blast and inhalation injury. Esophagus, trachea, heart, diaphragm, large vessels, lung, bone and soft tissue structures of the thoracic cavity may be injured. Physiological results of thoracic trauma are hypoxia, hypercarbia, hypovolemic shock - obstructive shock and acidosis. Poten- tially fatal pathologies after thoracic trauma are aortic dissection, myocardial contusion, trachea-bronchial laceration, esophageal perforation, massive lung contusion, diaphragmatic laceration with the hernia. Also, airway obstruction, tension and open pneumothorax, cardiac tamponade, massive hemothorax, and flail chest can be life-threatening without emergency intervention. Traumatic diaphragmatic injuries remain a diagnostic challenge. Undiagnosed small diaphragmatic lacerations may lead to serious health problems, such as the herniation, obstruction or strangulation of the abdominal organs to the thorax due to negative pressure in the following period. ${ }^{[3,4]}$ The present study aims to evaluate the role of VATS (Video-Assisted Thoracoscopic Surgery) in the diagnosis and treatment of diaphragmatic injuries after

Cite this article as: Yanık F, Karamustafaoğlu YA, Yörük Y. The role of VATS in the diagnosis and treatment of diaphragmatic injuries after penetrating thoracic traumas. Ulus Travma Acil Cerrahi Derg 2020;26:469-474.

Address for correspondence: Fazlı Yanık, M.D.

Trakya Üniversitesi Tıp Fakültesi, Göğüs Cerrahisi Anabilim Dalı, 22030 Edirne, Turkey

Tel: +90 284 - 235764 I / 4416 E-mail: fazliyanik@hotmail.com

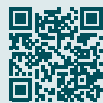

Ulus Travma Acil Cerrahi Derg 2020;26(3):469-474 DOI: 10.14744/tjtes.2019.02682 Submitted: 02.1I.2018 Accepted: 29.06.2019 Online: 13.05.2020

Copyright 2020 Turkish Association of Trauma and Emergency Surgery 
penetrating thoracic traumas which cannot be determined by radiologically.

\section{MATERIALS AND METHODS}

Among 268 penetrating thoracic trauma patients, we retrospectively evaluated a total of 22 patients who performed VATS due to suspected localization for diaphragmatic injury in our department between October 2010 and October 2018. Age, gender, type of trauma, applied treatments, complications and surgical and follow-up outcomes were evaluated. Penetrating traumas (stabbing, rifle gun injury and shotgun injury) suspected for having injured the diaphragm were included in this study. The entrance wound inferior to the nipple line or lower angle of the scapula should be suspected for diaphragmatic injury.

We evaluated all patients with chest Xray, computed tomography (with axial, sagittal and coronary sections) and abdominal ultrasonography. Routine hemostasis, hemogram parameters and biochemical blood tests examined. Additionally, the cardiac status of the patients was evaluated by serial serum cardiac enzyme determinations, electrocardiograms, and if need echocardiography. Additional traumatic pathologies were detected, and the patients were treated appropriately. Suspicious cases were prepared for explorative VATS. Patients who had blunt thoracic trauma, patients under 18 years of age, patients performed open surgical procedures, patients with missing data and non-suspect patients were excluded from our study. VATS was performed under general anesthesia with double-lumen intubation. We used $L$ shaped $10 \mathrm{~mm}$ 0-degree rigid thoracoscope (Karl-Storz GmbH \& Co. Tuttlingen, Germany). After the blood or the hematoma in the thoracic cavity was aspirated, diaphragm, lung, chest wall, the pericardium was explored for possible traumatic pathologies. The detected pathologies were treated with VATS. During VATS, pleural adhesions were dissected using electrocautery or with blunt dissection, if necessary. At the end of the operation, a $0,9 \%$ isotonic solution was fulfilled to the thorax, the lung was inflated and air leak control and intrapleural lavage were performed. All the patients were extubated in the operating theater and were followed in the high care unit of our service during the first 24 hours. Chest physiotherapy was applied in the early postoperative period. A portable chest $X$ ray was performed after surgery within hours. The chest tube of the cases was removed when there was no air leak, and the chest X-ray of the cases was fully expanded. The patients were discharged on the same day or the next day if their PA roentgenograms were normal after the chest tubes removal. All patients were routinely followed up monthly and yearly in our department.

\section{Data Analysis}

Statistical analysis was performed using the Statically Package for the Social Science program (SPSS, 20.0). Data were expressed as mean $\pm S D$. Frequencies and percentages were used for categorical measures. Student's $t$ and chi-square tests were used for statistical analysis for the difference between types of penetrating trauma, ages and gender of cases. $P<0.05$ were considered statistically significant.

\section{RESULTS}

Twenty-two consecutive cases with suspicious diaphragmatic injury were included in this study. 20 (91\%) patients were male and two $(9 \%)$ patients were female with a mean age of $28.01 \pm 6.4$ (I8-42). In I I (50\%) patients, VATS was performed on the right side (seven of them anterior, four of them posterior hemithorax located), the others on the left side according to penetrating the area of trauma (five of them anterior, six of them posterior hemithorax located) (Figs. la, b).

All patients underwent uniportal VATS with the help of thoracal applied from the 5 th intercostal space. An utility incision was opened in $10(45 \%)$ patients with a diaphragmatic laceration. Eight of these 10 patients ( $80 \%$ ) were localized in left hemithorax and two in the right hemithorax. No herniation was observed in any case (Table I, Fig. 2). The diaphragm was repaired primary using unabsorbable 0 number non- absorbable sutures in these patients. In six cases $(27 \%)$ diaphragmatic laceration detected with VATS, pneumotho$\operatorname{rax}(n=2)$, hemothorax $(n=2)$, pulmonary contusion $(n=1)$ and hemopneumothorax $(n=l)$ were radiologically. The diaphragmatic injury was detected in four patients although no

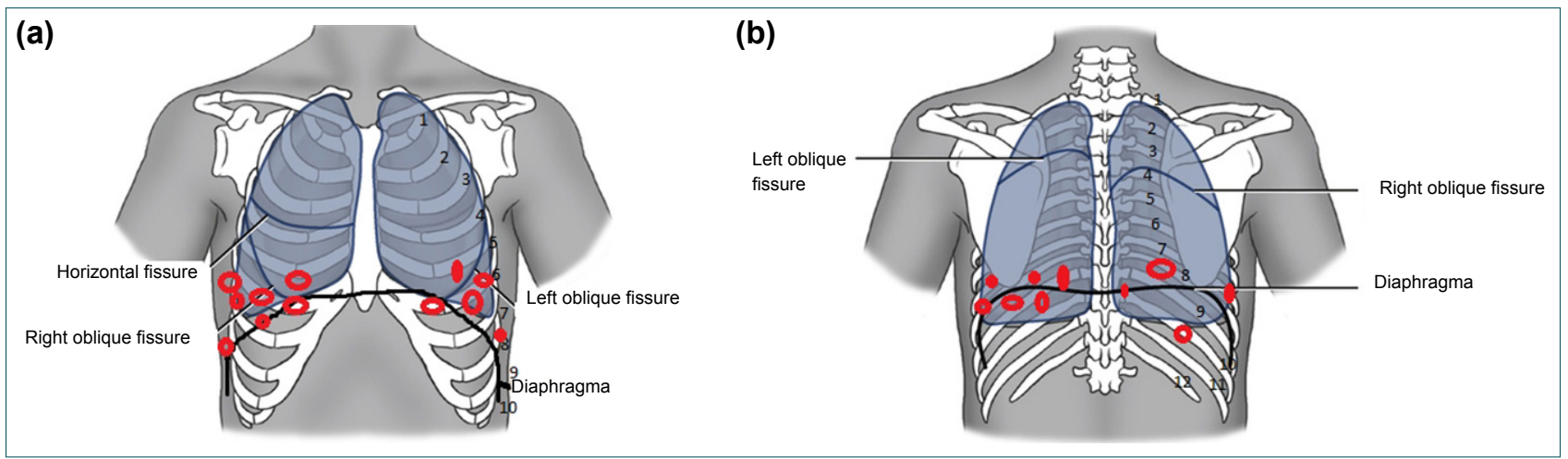

Figure 1. Configuration of the penetrating tool entry holes in the (a) anterior (b) posterior hemithorax. 
Table I. Demographic and clinical characteristics and surgical outcomes of the 22 cases

\begin{tabular}{|c|c|}
\hline Sex, n (\%) & $22(100)$ \\
\hline Male & $20(91)$ \\
\hline Female & $2(9)$ \\
\hline Age, mean $\pm S D$ (range, years) & $28.01 \pm 6.4(18-42)$ \\
\hline $\begin{array}{l}\text { Mean operation time, } \\
\text { mean } \pm S D \text { (range, min) }\end{array}$ & $24.02 \pm 4.52(18-50)$ minutes \\
\hline $\begin{array}{l}\text { Mean tube removal time, } \\
\text { mean } \pm S D \text { (range, } \min )\end{array}$ & $\mathrm{I} .3 \pm 0.5(\mathrm{I}-4)$ days \\
\hline $\begin{array}{l}\text { Mean lenght of hospital time, } \\
\text { mean } \pm S D \text { (range, } \mathrm{min} \text { ) }\end{array}$ & $1.9 \pm 0.9(2-5)$ days \\
\hline Acces of VATS, $n(\%)$ & $22(100)$ \\
\hline Right $^{*}$ & II (50) \\
\hline Left $^{* *}$ & II (50) \\
\hline Type of penetrating trauma, $n$ (\%) & $22(100)$ \\
\hline Stabbing & $12(55)$ \\
\hline Rifle gun injury & $6(27.5)$ \\
\hline Shotgun injury & $4(17.5)$ \\
\hline \multicolumn{2}{|l|}{ detection with VATS, n (\%) } \\
\hline Yes & $10(45)$ \\
\hline No & $12(55)$ \\
\hline Complications, n (\%) & $2(9)$ \\
\hline Expansion problems & I (4.5) \\
\hline Wound infection & I (4.5) \\
\hline
\end{tabular}

*7 of them anterior, 4 of them posterior hemithorax located (Figure la, b); $* * 5$ of them anterior, 6 of them posterior hemithorax located (Figure la, b). SD: Standard deviation; VATS: Video-Assisted Thoracoscopic Surgery

radiological images were found. The missed injury rate was $18 \%$. The specificity, sensitivity, positive predictive value and negative predictive value of VATS were $75 \%, 71.5 \%, 60 \%$ and $83.3 \%$, respectively, detection of the diaphragm injury after penetrating trauma in our study.

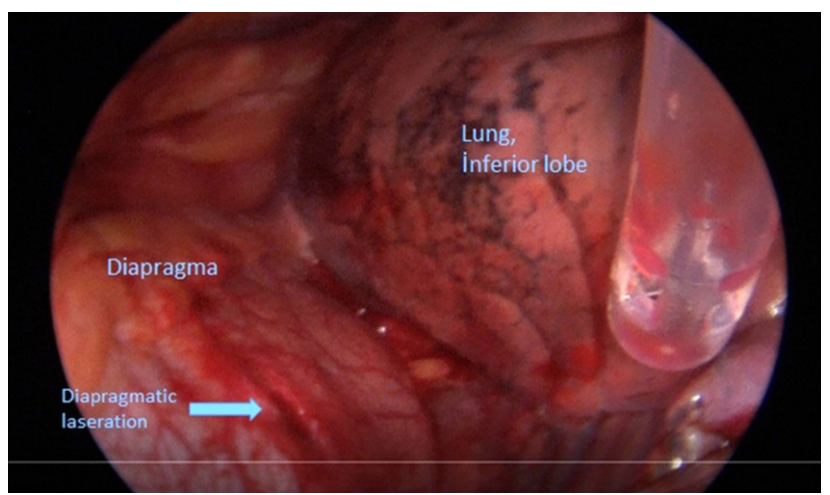

Figure 2. Thoracoscopic view of the diaphragmatic laceration after penetrating trauma in the left anterior hemithorax, 6th intercostal space (Stabbing), marked with a blue arrow.
Table 2. Detected additional traumatic pathologies for the 22 patients

\begin{tabular}{lcc}
\hline & n & $\%$ \\
\hline Additional traumatic pathology for thorax & 15 & 68 \\
Pulmonary contusion & 6 & 27.5 \\
Pneumothorax & 4 & 18 \\
Hemothorax & 3 & 13.5 \\
Hemopneumothorax & I & 4.5 \\
Pericardial laceration & I & 4.5 \\
Additional traumatic pathology for out of thorax & 10 & 45 \\
Liver laceration & 4 & 18 \\
Spleen laceration & 3 & 13.5 \\
Tendon rupture & 2 & 9 \\
Scalp laceration & I & 4.5 \\
\hline
\end{tabular}

While conservative treatment was administered in six patients with pulmonary contusion $(n=6)$, tube thoracostomy was performed in patients with pneumothorax $(n=4)$, hemothorax $(n=3)$ and hemopneumothorax $(n=1)$ for another traumatic pathology. Liver laceration $(n=4)$, spleen laceration $(n=3)$, tendon rupture in the forearm $(n=2)$ and scalp laceration $(n=l)$ were the most frequent accompanying injury (Table 2). While all the liver lacerations were treated conservatively, splenectomy was carried out for splenic laceration and tendon cut and scalp wound was repaired by other branches synchronously (Table 2).

The mean operation time, chest tube removal time, length of hospital stay time were $24.02 \pm 4.52$ (18-50) minutes, I.3 \pm 0.5 (1-4) days, $1.9 \pm 0.9$ (2-5) days, respectively. The mean loss of blood was less than $150 \mathrm{ml}$. There was no conversion to open thoracotomy and intraoperative complications were not seen. Intraoperative or postoperative mortality was not observed. Complications were developed in two (9\%) patients; as expansion problem in one (4.5\%) patient and wound infection in one $(4.5 \%)$ patient. Space was managed successfully with external suction and chest physiotherapy to provide lung expansion. The patient who developed wound infection was treated with broad-spectrum i.v. antibiotics and daily dressing. There was no significant statistical difference between types of penetrating trauma, ages and gender of cases $(p>0.05)$.

The mean follow-up period was 36.2 \pm 9.3 (range 9-62) months. During this follow-up period, pulmonary function tests and chest $\mathrm{X}$-rays were performed. Clinical changes, recovery and complications were evaluated. No diaphragmatic hernia or traumatic pathology was detected in any patient during the follow-up. 
The other demographic and clinical data and surgical outcomes are summarized in Table I.

\section{DISCUSSION}

Thoracic diaphragmatic injury may occur after the blunt thoracic trauma and $15 \%$ of penetrating thoracic trauma. It is reported that $2 / 3$ of all diaphragmatic injuries are blunt and $1 / 3$ arises from penetrating trauma. The left side affects more than the right hemithorax..$^{[5,6]}$ In our case series, penetrating thoracic traumas were localized right hemithorax in II (50\%) patients and left hemithorax in II (50\%) cases. However, we detected diaphragmatic laceration in 10 out of 22 suspected patients. $80 \%$ of these injuries were on the left hemithorax.

Diaphragmatic injuries can be divided into three groups as acute, latent and late. Acute diaphragmatic injury is detected within 0-14 days after injury. Latent diaphragmatic injury is diagnosed after acute injury but before intestinal obstruction or strangulation. Late diaphragmatic injury is diagnosed with intestinal obstruction or strangulation. It is difficult to diagnose small diaphragmatic lacerations. ${ }^{[4-6]}$ All of our cases were evaluated with exploratory VATS within 48 hours. No herniation was observed in any case.

These cases may show signs of herniation of the abdominal organs to the thorax due to negative intrathoracic pressure and positive intraabdominal pressure after the months or years. Since the abdominal organs such as colon, stomach, spleen and omentum are herniated into the thorax through a small laceration on the diaphragm. This may cause rapid necrosis, sepsis and unexpected death in undiagnosed cases. [5-7] Therefore, we think that exploratory VATS is very important in every suspected case of penetrating trauma.

In acute diaphragmatic injury, non-absorbable (0 or I number) sutures should be used for primary repair. However, the repair should be supported by prosthetic meshes to strengthen the diaphragm in large defects or chronic cases. [8] The diaphragm was repaired primary using unabsorbable 0 number non-absorbable sutures in $45 \%$ of patients with acute diaphragm laceration by penetrating trauma in our study. We did not need prosthetic material.

Diaphragm moves between the 4-8 ribs with deep expiration and inspiration. Topographically, penetrating injuries under the $5^{\text {th }}$ intercostal space in the anterior hemithorax and lower end of the scapula in the posterior hemithorax are suspected cases for diaphragmatic laceration. Therefore, diaphragmatic injury should be ruled out in lower of these levels. Otherwise, minor injuries may cause fatal complications in the long term interval. ${ }^{[2,9]}$ Penetrating traumas (stabbing, rifle gun injury and shotgun injury) which suspected for having injured the diaphragm were included in our study. The entrance holes in the area below the $5^{\text {th }}$ intercostal space in the anterior hemithorax and the area under the scapula in the posterior hemithorax were considered as suspected cases.

The symptoms of diaphragmatic injury may include shoulder or epigastric pain, severe cough, respiratory distress and intrathoracic bowel sounds. The presence of abdominal symptoms in a person with thoracic injury raises suspicion for diaphragmatic injury. Furthermore, in cases of delayed presentation with chronic herniation, symptoms of partial or complete intestinal obstruction - strangulation may be present. ${ }^{[6,10]}$ All of our cases are asymptomatic. Because of the localization of penetrating injury, exploratory VATS was performed to all of them due to their suspicion of diaphragm injury.

In addition to direct X-ray, thoraco-abdominal tomography should be performed in a patient with penetrating trauma who is a suspect diaphragmatic injury. Abnormalities in chest radiography include hemothorax, pneumothorax, hemopneumothorax, the herniated image of the abdominal organ to the thorax or pneumoperitoneum. However, it may not provide any radiological findings. ${ }^{[\prime]}$ We evaluated all patients using Chest Xray. Full-body computed tomography (with axial, sagittal and coronary sections) and abdominal. We did not detect the herniated image of the abdominal organ to the thorax or pneumoperitoneum. Herniation to the thorax was not seen in our study because of rapid intervention. However, we detected pulmonary contusion in six patients, pneumothorax in four patients, hemothorax in three patients and hemopneumothorax in one patient. In six cases, diaphragmatic laceration was detected with VATS, while additional radiological findings were present. Although no radiological finding was observed in four cases, the diaphragmatic injury was detected.

The diagnosis of diaphragm injury can be difficult for trauma surgeons. Using many non-invasive methods, including physical examination, chest $\mathrm{X}$-ray, computed tomography, magnetic resonance imaging and diagnostic peritoneal lavage, a preoperative diagnosis can be obtained only about $70 \%$ on time. ${ }^{\left[{ }^{12]}\right.}$ Paci et al. ${ }^{[13]}$ reported that a diaphragmatic injury in five $(38.5 \%)$ of 13 patients who had penetrating thoracic trauma. Furthermore, one patient needed conversion from VATS to open operation due to a broad laceration of the diaphragm and diaphragm laceration missed with radiologic methods in the whole of 13 patients in their study. Diaphragmatic lacerations without herniation are difficult to diagnose. We think that VATS is a standard indication for the hemodynamically stable patient who presents with acute penetrating thoracic trauma. In addition to possible accompanying traumatic pathologies, VATS in small diaphragmatic lacerations and accompanying traumatic pathologies are extremely useful both diagnostically and therapeutically. Furthermore, other advantages of VATS were fewer postoperative complications, better postoperative pain control, 
fewer wound and pulmonary complications, shorter chest tube duration, and a faster return to regular activities compared to thoracotomy. ${ }^{[10-13]}$

Martinez et al. ${ }^{[14]}$ reported missed injury rate in penetrating thoracic trauma is approximately $30 \%$. They take attention that all radiological images can be non-pathological in more than $70 \%$ of these patients. We found s missed injury rate as $18 \%$. In properly selected patients, localization penetrating trauma may increase this rate.

Pekmezci et al. ${ }^{[5]}$ reported that VATS, which may perform both local anesthesia, or general anesthesia is a safe and effective procedure in the diagnosis and treatment of penetrating thoracoabdominal diaphragmatic injuries. We did not try a diaphragmatic repair with VATS in any patient with the help of local anesthesia in our study.

\section{Conclusion}

We conclude that the diagnosis of diaphragmatic injuries due to penetrating thoracic trauma is difficult to detect radiologically. Hidden injuries may lead to serious complications in the later period. VATS should be performed for both diagnosis and treatment in suspected penetrating thoracic trauma cases in which the diagnosis cannot be reached by imaging methods.

Informed Consent: Written informed consent was obtained from the patients for the publication of the case report and the accompanying images.

Peer-review: Internally peer-reviewed.

Authorship Contributions: Concept: F.Y., Y.A.K.; Design: F.Y., Y.A.K.; Supervision: Y.A.K., Y.Y.; Fundings: F.Y., Y.Y.; Materials: F.Y., Y.A.K.; Data: F.Y.; Analysis: F.Y., Y.A.K., Y.Y.; Literature search: F.Y., Y.A.K.; Writing: F.Y., Y.A.K., Y.Y.; Critical revision: Y.A.K., Y.Y.

Conflict of Interest: None declared.

Financial Disclosure: The authors declared that this study has received no financial support.

\section{REFERENCES}

1. Dennis BM, Bellister SA, Guillamondegui OD. Thoracic Trauma. Surg Clin North Am 2017;97:1047-64. [CrossRef]

2. Kulshrestha P, Munshi I, Wait R. Profile of chest trauma in a level I trauma center. J Trauma 2004;57:576-81. [CrossRef]

3. Paydar S, Johari HG, Ghaffarpasand F, Shahidian D, Dehbozorgi A, Ziaeian $\mathrm{B}$, et al. The role of routine chest radiography in initial evaluation of stable blunt trauma patients. Am J Emerg Med 2012;30:1-4. [CrossRef]

4. Okan I, Baş G, Ziyade S, Alimoğlu O, Eryılmaz R, Güzey D, et al. Delayed presentation of posttraumatic diaphragmatic hernia. Ulus Travma Acil Cerrahi Derg 2011;17:435-9. [CrossRef]

5. Thiam O, Konate I, Gueye ML, Toure AO, Seck M, Cisse M, et al. Traumatic diaphragmatic injuries: epidemiological, diagnostic and therapeutic aspects. Springerplus 2016;5:1614. [CrossRef]

6. Ray MS, Deepak BS, Kumar R. Traumatic diaphragmatic injury: case report. Int Surg J 2016;3:2347-50. [CrossRef]

7. Meyers BF, McCabe CJ. Traumatic diaphragmatic hernia. Occult marker of serious injury. Ann Surg 1993;218:783-90. [CrossRef]

8. Hanna WC, Ferri LE. Acute traumatic diaphragmatic injury. Thorac Surg Clin 2009;19:485-9. [CrossRef]

9. Kumar S, Pol M, Mishra B, Sagar S, Singhal M, Misra MC, et al. Traumatic Diaphragmatic Injury: A Marker of Serious Injury Challenging Trauma Surgeons. Indian J Surg 2015;77:666-9. [CrossRef]

10. Hanna WC, Ferri LE, Fata P, Razek T, Mulder DS. The current status of traumatic diaphragmatic injury: lessons learned from 105 patients over 13 years. Ann Thorac Surg 2008;85:1044-8. [CrossRef]

11. Iochum S, Ludig T, Walter F, Sebbag H, Grosdidier G, Blum AG. Imaging of diaphragmatic injury: a diagnostic challenge?. Radiographics 2002;22:S103-18. [CrossRef]

12. Ochsner MG, Rozycki GS, Lucente F, Wherry DC, Champion HR. Prospective evaluation of thoracoscopy for diagnosing diaphragmatic injury in thoracoabdominal trauma: a preliminary report. J Trauma 1993;34:704-10. [CrossRef]

13. Paci M, Ferrari G, Annessi V, de Franco S, Guasti G, Sgarbi G. The role of diagnostic VATS in penetrating thoracic injuries. World J Emerg Surg 2006;1:30. [CrossRef]

14. Martinez M, Briz JE, Carillo EH. Video thoracoscopy expedites the diagnosis and treatment of penetrating diaphragmatic injuries. Surg Endosc 2001;15:28-33. [CrossRef]

15. Pekmezci S, Kaynak K, Saribeyoğlu K, Memişoğlu K, Kurdal T, Kol E, et al. Thoracoscopy in the diagnosis and treatment of thoracoabdominal stab injuries. Ulus Travma Acil Cerrahi Derg 2007;13:36-42. 
OLGU SERİİ - ÖZET

\section{Penetran toraks travmalarından sonra görülebilen diyafragma yaralanmalarının tanı ve tedavisinde VATS'nin rolü \\ Dr. Fazlı Yanık, Dr. Yekta Altemur Karamustafaoğlu, Dr. Yener Yörük}

Trakya Üniversitesi Tıp Fakültesi, Göğüs Cerrahisi Anabilim Dalı, Edirne

AMAÇ: Penetran torasik travması sonrasında görülebilen diyafragma yaralanmalarının tanısında bazı zorluklar yaşanabilmektedir. Tanı konulamamış küçük diyafragma yaralanmaları, sonraki dönemde ciddi sağlık sorunlarına yol açabilirler. Bu çalışmanın amacı, penetran toraks travması sonrasında görülebilen diyafragma yaralanmalarının tanı ve tedavisinde VATS’nin (Video Yardımlı Torakoskopik Operasyonlar) rolünü değerlendirmektir. GEREÇ VE YÖNTEM: Bu çalışmada, 268 penetran toraks travmalı hasta arasından, Haziran 2008 ile Haziran 20 I 8 tarihleri arasında bölümümüzde diyafragma yaralanması şüphesi ile VATS uygulanan toplam 22 hasta geriye dönük olarak değerlendirildi.

BULGULAR: Yirmi (\%9I) hasta erkek, iki hasta (\%9) kadın olup, yaş ortalamaları 28.0 I \pm 6.4 (I8-42) yıldı. Penetran travmanın yerine göre I I (\%50) hastada sağ taraftan, diğerlerine sol taraftan VATS yapıldı. On (\%45) hastada diyafragma laserasyonu tespit edildi ve tamir edildi. VATS ile diyafragma laserasyonunun saptanan altı olguda (\%27) radyolojik olarak ek travmatik patolojiler saptandı. Radyolojik olarak yaralanmanın atlanma oranı \% I 'di. VATS'ın özgüllüğü, duyarlılı̆ı, pozitif prediktif değeri ve negatif prediktif değerini sırasıyla \%75, \%7।.5, \%60 ve \%83.3 olarak hesaplandı. Penetran

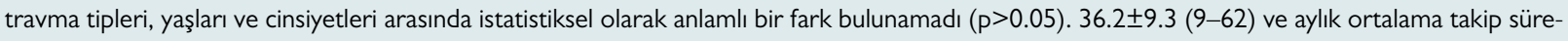
since hiçbir komplikasyon görülmedi.

TARTIŞMA: Penetran toraks travma sonrası şüpheli izole diyafragma laserasyonu düşünülen, radyolojik olarak belirlenemeyen hemodinamik olarak stabil hastalarda VATS'ın önemli ve uygulanabilir olduğu görüşündeyiz.

Anahtar sözcükler: Diyafragma; penetran; torakoskopi; travma.

Ulus Travma Acil Cerrahi Derg 2020;26(3):469-474 doi: 10.14744/tjtes.2019.02682 